\title{
Applying Indicators of Hydrologic Alteration to Texas Streams- Overview of Methods With Examples From the Trinity River Basin
}

Streamflow is a component of aquatic ecosystem health, and long-term alteration of streamflow characteristics can produce large changes in aquatic ecosystem structure and function. The physical, chemical, and biological properties of aquatic ecosystems are all affected by the magnitude and frequency of streamflow. For example, the physical structure (hydrogeomorphology) of aquatic habitats is a property of the interaction between streamflow magnitude and frequency and the physical landscape (Leopold and others, 1992). Chemical processes are affected by changes in water residence time, which is a function of streamflow. Similarly, the structure and function of biological communities associated with stream ecosystems depend in large part on the hydrologic regime (Poff and Ward, 1989, 1990; Sparks, 1992). Within-year variation in streamflow is essential to the survival, growth, and reproduction of aquatic species. Altering streamflow magnitude and frequency and within-year variability has the potential to modify critical aspects of the physical habitat (Bain and others, 1988).

Documenting the degree to which streamflow has been modified by the cumulative effects of water development is critical to assessing aquatic ecosystem health. The U.S. Geological Survey (USGS), in cooperation with the Texas Commission on Environmental Quality, conducted a study of the application of the Indicators of Hydrologic Alteration (IHA) methods developed by Richter and others $(1996,1997)$ to identify streams at risk for biological impairment from the loss of streamflow-dependent habitat. This report provides a brief overview of selected IHA methods for assessing hydrologic alteration; presents examples that illustrate the application of the methods using streamflow data from a subset of USGS stations in the Trinity River Basin, Texas, analyzed in the study; and addresses applicability of the methods statewide.

\section{Overview of Methods}

The IHA methods characterize within-year variation in streamflow on the basis of a series of hydrologic attributes (IHA statistics) organized into five groups (table 1). Alteration of the streamflow regime indicated by changes in these statistics provides insight into temporal changes in flow-dependent habitat. If IHA statistics track variables that affect survival and reproduction of aquatic organisms, then historical patterns in the rate of change of an IHA statistic or a sudden discrete alteration in an IHA statistic are useful in developing restoration criteria.

For this report, a subset of the IHA statistics was selected for analysis: The 11 IHA statistics from Groups 1 and 2, and two of the four statistics from Group 4 were computed from historical USGS daily mean streamflow for five continuous streamflowgaging stations. Continuous streamflow stations were selected on the basis of length of record (20 years or longer), flow characteristics (perennial flow), location relative to major reservoirs, and in some cases location relative to historical biological surveys. The Group 1 statistic (mean monthly streamflow) reflects seasonal patterns in the magnitude and timing of streamflow. For this report, average monthly median streamflow - that is, the average of all the January medians over the period of record, the average of all the February medians, and so forth-rather than mean monthly streamflow was the Group 1 statistic, the rationale for which is discussed later. IHA Group 2 statistics focus on the magnitude and duration of annual extreme flow conditions. For each station, annual maximum and minimum 1-, 3-, 7-, 30-, and 90-day means were computed from moving averages of those attributes over the period of record. IHA Group 4 statistics measure the frequency of high- and low-flow pulses in the aquatic environment.

Table 1. Summary of hydrologic attributes used in the Indicators of Hydrologic Alteration and their characteristics (modified from Richter and others, 1996)

[IHA, Indicators of Hydrologic Alteration; *, attribute used in this report]

\begin{tabular}{clc}
\hline $\begin{array}{c}\text { IHA statistics } \\
\text { group }\end{array}$ & $\begin{array}{c}\text { Regime } \\
\text { charac- } \\
\text { teristics }\end{array}$ & Hydrologic attributes \\
\hline $\begin{array}{c}\text { Group 1: Magnitude } \\
\text { of monthly water }\end{array}$ & $\begin{array}{l}\text { Magnitude } \\
\text { Timing }\end{array}$ & Mean for each calendar month (median \\
conditions & & in this application)
\end{tabular}

Group 2: Magnitude Magnitude * Annual minimums of 1-day means and duration of Duration * Annual maximums of 1-day means annual extreme $\quad *$ Annual minimums of 3-day means water conditions $\quad *$ Annual maximums of 3-day means

* Annual minimums of 7-day means

* Annual maximums of 7-day means

* Annual minimums of 30-day means

* Annual maximums of 30-day means

* Annual minimums of 90-day means

* Annual maximums of 90-day means

Group 3: Timing of Timing Julian date of each annual 1-day maximum annual extreme Julian date of each annual 1-day minimum water conditions

Group 4: Frequency Magnitude * Number of high-flow pulses each year and duration of Frequency * Number of low-flow pulses each year high- and low- Duration Mean duration of high-flow pulses in each year flow pulses Mean duration of low-flow pulses in each year

Group 5: Rate and Frequency Means of all positive differences between frequency of Rate of consecutive daily means water-condition change Means of all negative differences between changes consecutive daily means

Number of rises Number of falls 
A pulse in this context is defined as a daily mean flow above or below selected thresholds. For each station, the two Group 4 statistics were defined, respectively, as the annual number of daily mean flows greater than the 75th percentile and the annual number less than the 25th percentile over the period of record.

The results of the computations are thus datasets of annual series of attributes for the respective periods of record. Statistically significant changes in IHA statistics over a sufficiently long period of record indicate that hydrology has been altered. Hence, tests for significant trends in selected IHA statistics can be done; for this report, a hypothesis test for nonzero slope of regression (Helsel and Hirsch, 1992) was used on Groups 2 and 4 statistics. For stations at which flow is affected by one or more upstream reservoirs, IHA statistics can be tested for significant differences between pre- and post-impoundment flow regimes; for this report, the Kruskal-Wallis test (Helsel and Hirsch, 1992) was used on the Group 1 statistic. In terms of potential biological importance, the size of detectable changes in IHA statistics over time might be more important than whether the changes are statistically significant (Richter and others, 1996).

\section{Application of Indicators of Hydrologic Alteration in the Trinity River Basin}

The lengths of daily streamflow record for the five Trinity River Basin stations selected range from about 43 to 80 years. Flow at some stations is affected by reservoirs impounded during the respective periods of record (fig. 1), and historical biological surveys also have been conducted near some stations.

Analysis of Group 2 statistics indicates significant upward trends at the .05 level in the annual 7-day minimum flows at the

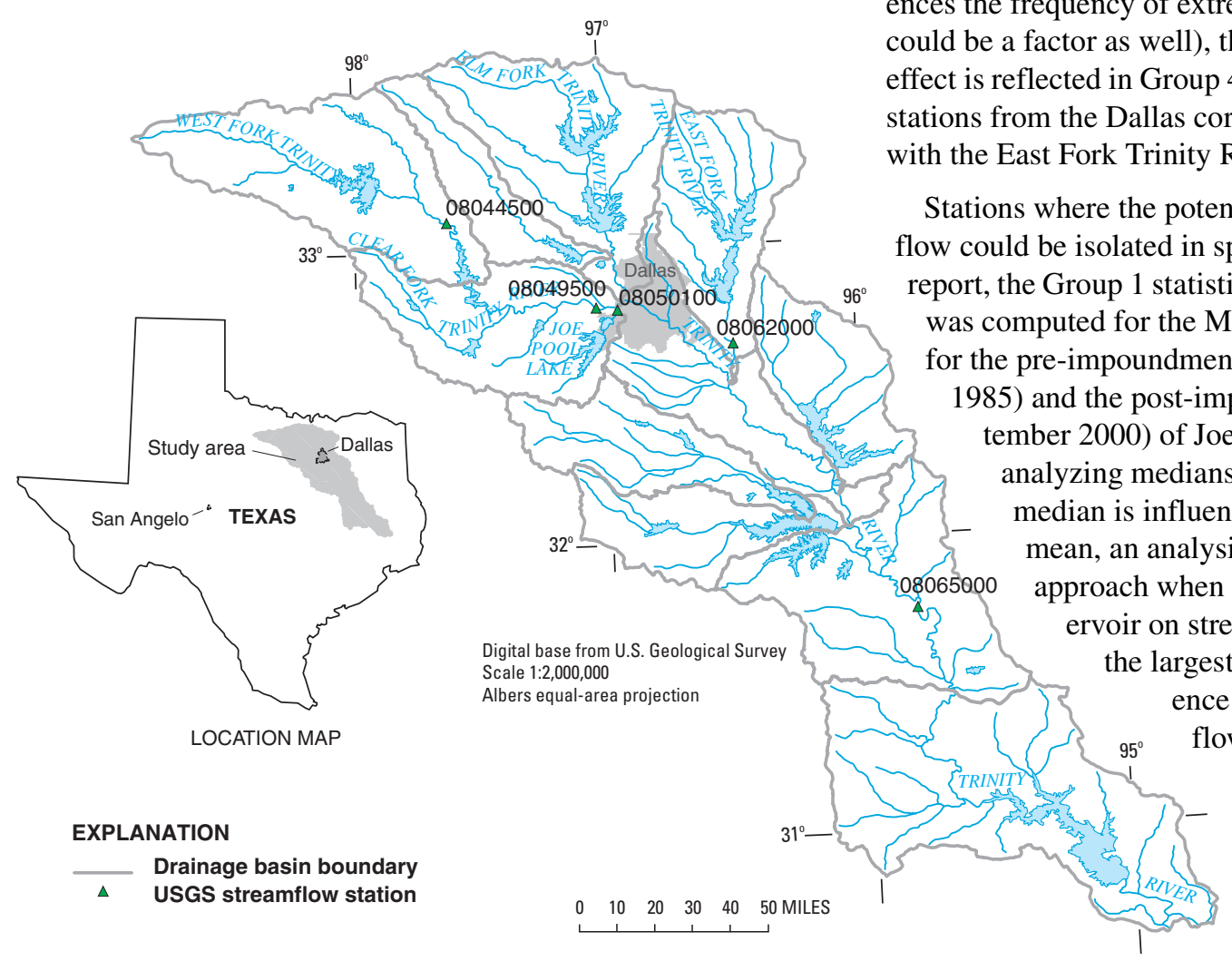

Figure 1. Location of USGS streamflow-gaging stations in the Trinity River Basin, Texas.
West Fork Trinity River at Grand Prairie station, at the (main stem) Trinity River near Oakwood station, and at the East Fork Trinity River near Crandall station (fig. 2). The 7-day minimums at those three stations also show long-term decreases in variability. Some magnitudes of change over time might be large enough to have biological effects. For example, the average annual 7-day minimum for the Trinity River near Oakwood for the approximate second half of the record (585 cubic feet per second for 19612000) is nearly three times that of the approximate first half of the record (201 cubic feet per second for 1924-61).

For the Trinity River Basin stations, IHA Group 4 statistics show significant downward trends at the .05 level in the annual frequency of low-flow pulses over the periods of record (fig. 3). For example, the average number of low-flow pulses for the West Fork Trinity River near Boyd during 1951-75 (10.6) was about twice the average number during 1976-2000 (5.24). During the periods of record, the annual frequency of high-flow pulses showed upward trends, although they generally were less than the downward trends in frequency of low-flow pulses and were not significant. An exception is the West Fork Trinity River at Grand Prairie (fig. 3c), which showed a significant upward trend in frequency of high-flow pulses during its 76-year period of record.

Although the IHA method "allows estimation of the magnitude of impacts but does not enable strong inferences regarding the cause" (Richter and others, 1996, p. 1,168), the only station with significant trends in frequency of both high- and low-flow pulses (West Fork Trinity River at Grand Prairie) also is the station most strongly influenced by urban development, including reservoirs. Upstream influences on this station include the Fort Worth and Arlington metropolitan areas, numerous reservoirs, and major wastewater discharges. To the extent that such development influences the frequency of extreme flow events (climatic change could be a factor as well), this combined urban and reservoir effect is reflected in Group 4 statistics for main-stem Trinity River stations from the Dallas corridor downstream to the confluence low could be isolated in space and time were identified. For this report, the Group 1 statistic average monthly median streamflow was computed for the Mountain Creek at Grand Prairie station or the pre-impoundment period (October 1960-December

(January 1986-Sepof medians is the more conservative voir on streamflow. Reservoirs commonly reduce eamflows, thus a significant difference in pre- and post-impoundment mean flows is likely; whereas a significant preand post-impoundment difference in medians is less likely and might be a truer indicator of change in central tendency of the flow regime.

Joe Pool Lake is an 11.7-squaremile reservoir on Mountain Creek 
(a) 08049500

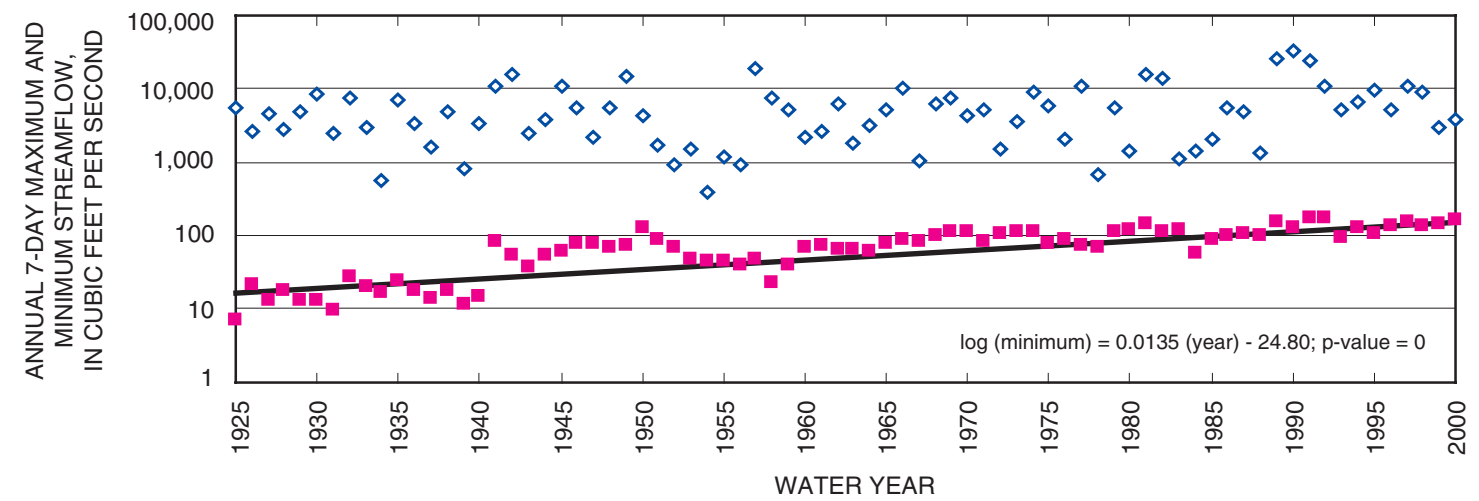

(b) 08065000

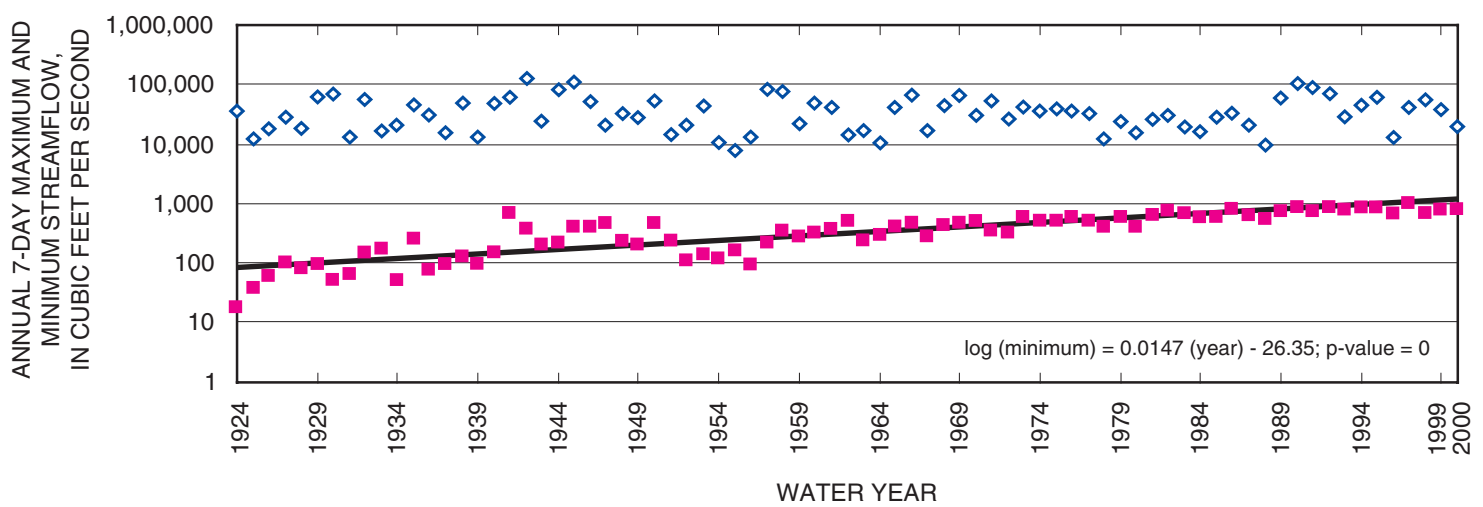

(c) 08062000

\section{EXPLANATION}

$\diamond 7$-day maximum streamflow

- 7-day minimum streamflow

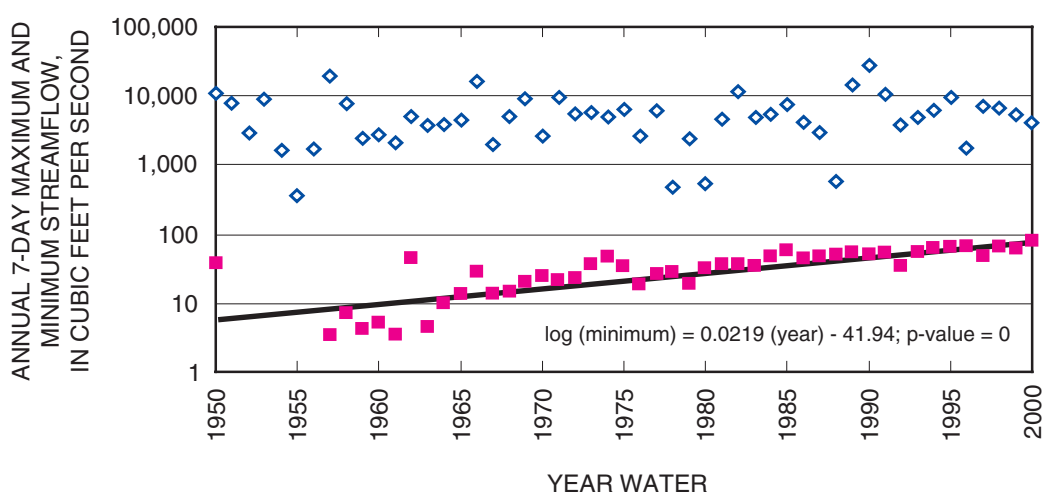

Figure 2. Annual 7-day maximum and minimum streamflows for (a) West Fork Trinity River at Grand Prairie, Texas (08049500), water years 1925-2000, (b) Trinity River near Oakwood, Texas (08065000), water years 1924-2000, and (c) East Fork Trinity River near Crandall, Texas (08062000), water years 1950-2000.

about 9 miles upstream from the Grand Prairie streamflow-gaging station. Comparisons of average monthly median streamflow between the pre- and post-impoundment periods show substantial differences. Kruskal-Wallis tests indicate the differences are significant at the .1 level for all months and significant at the .05 level for 10 of 12 months. Average median monthly flows from winter through mid-summer (November-July) increased greatly during the post-impoundment period; late summer and early fall flows (August-October) changed little.

The long-term pattern in average monthly median streamflow downstream of Joe Pool Lake can be contrasted with that for streams below reservoirs in other areas of Texas. For example, the pattern in the Colorado River about 35 miles downstream from E.V. Spence Reservoir (a 23.3-square-mile water body about 30 miles north of San Angelo) is very different. Average monthly median streamflow at the Colorado River near Ballinger station generally shows change in pre- and post-impoundment flows opposite to that of the Mountain Creek at Grand Prairie station (fig. 4b). At the Colorado River station, pre-impoundment flows for most of spring, summer, and most of fall (April-November) were significantly greater at the .05 level than post-impoundment flows; the relatively small changes between pre- and postimpoundment flows in winter (December-March) were not significant. 
(b) 08065000
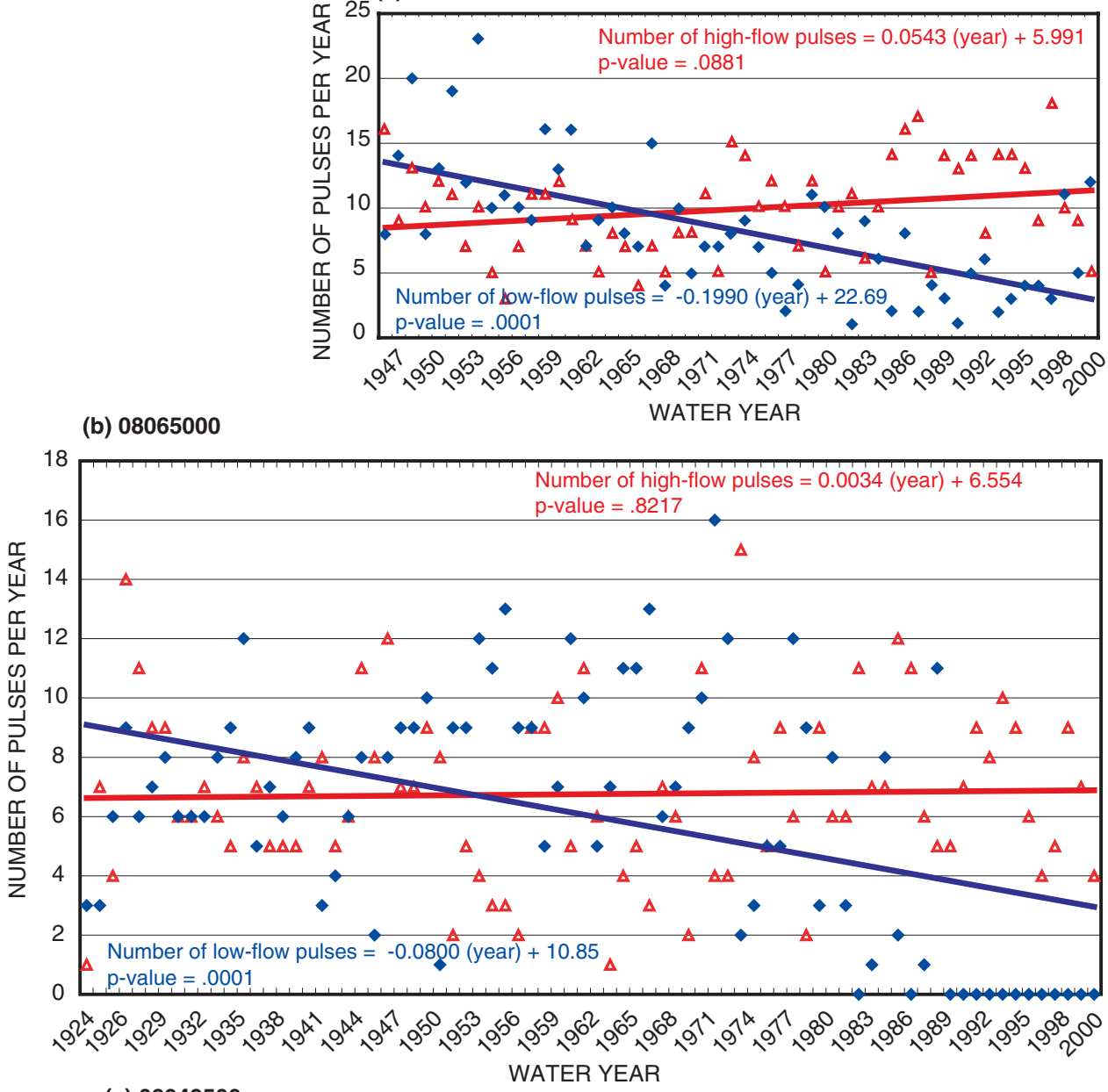

(c) 08049500

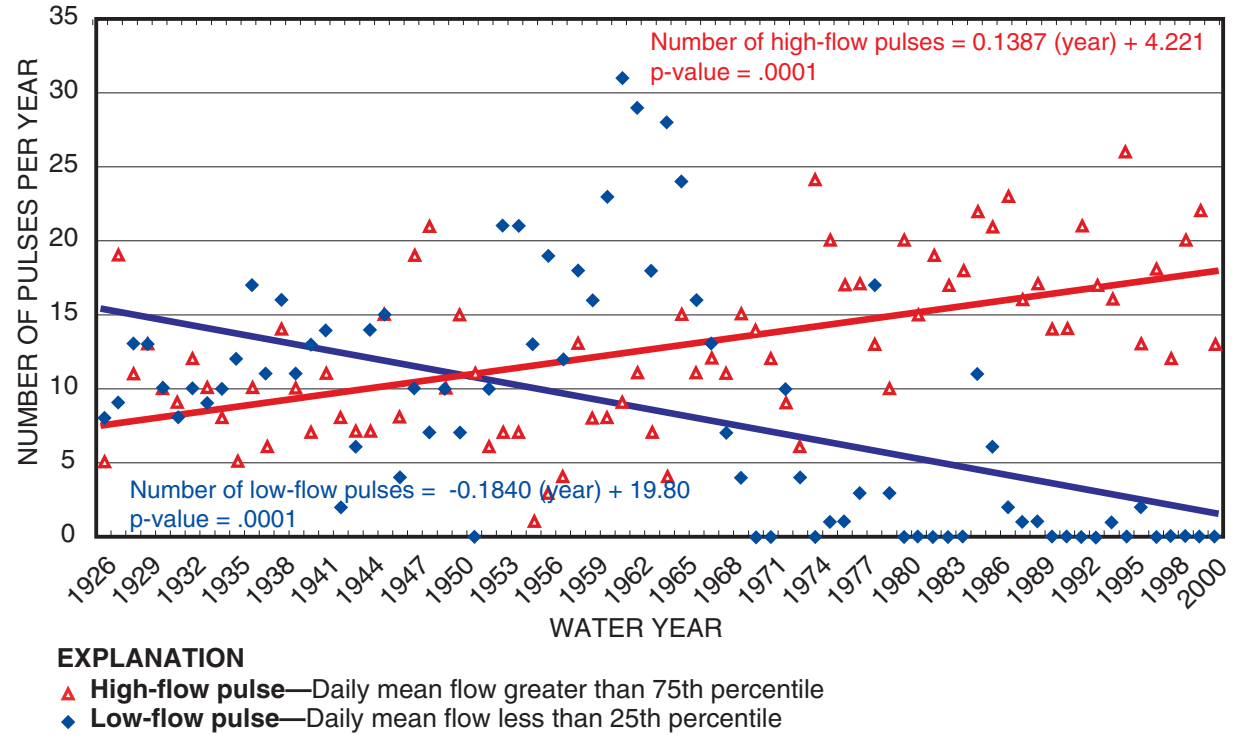

Figure 3. Annual frequency of high- and low-flow pulses for (a) West Fork Trinity River near Boyd, Texas (08044500), water years 1947-2000, (b) Trinity River near Oakwood, Texas (08065000), water years 1924-2000, and (c) West Fork Trinity River at Grand Prairie, Texas (08049500), water years 1925-2000.

The frequency of low-flow pulses at the Mountain Creek station below Joe Pool Lake showed different trends between the pre- and post-impoundment periods (fig. 5). The frequency of low-flow pulses decreased 3 years after impoundment (took 3 years for the lake to fill) and remained low throughout the succeeding post-impoundment period. In contrast, the frequency of high-flow pulses remained essentially unchanged during the post-impoundment period. 
(a) 08050100

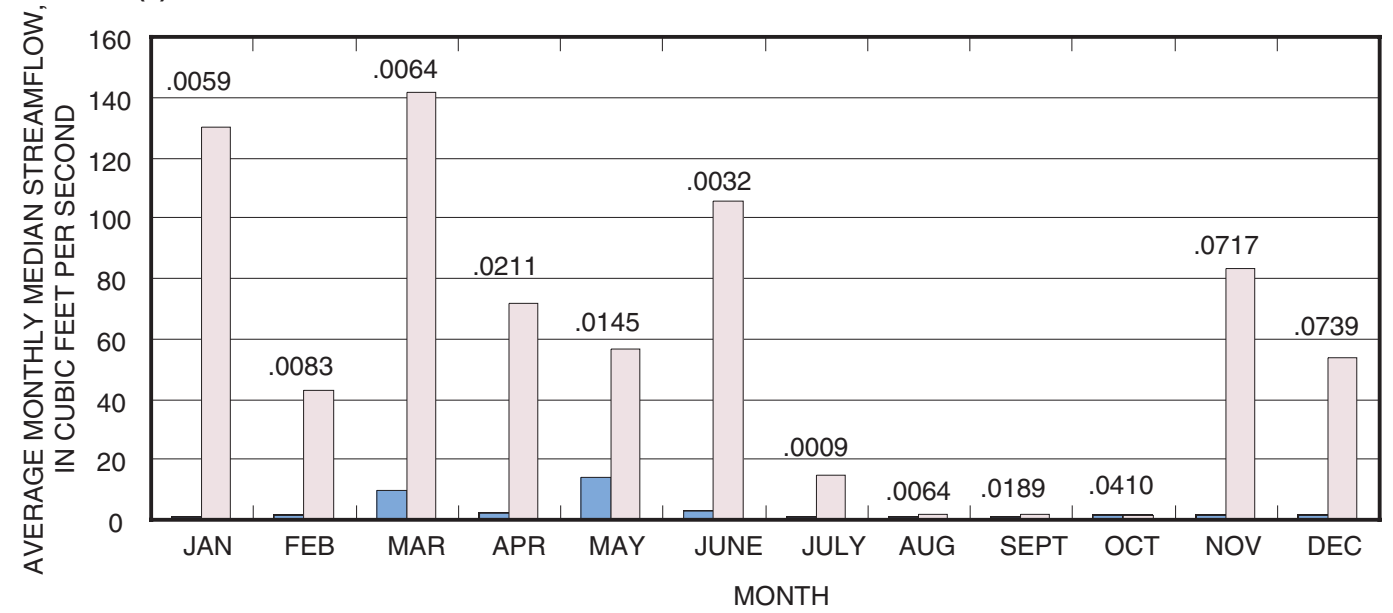

EXPLANATION

.0145 - p-value, Kruskal-Wallis test for significant difference between pre- and post-impoundment flow

Post-impoundment period

Joe Pool Lake-Jan. 1986-Sept. 2000

Pre-impoundment period

Joe Pool Lake-Oct. 1960-Dec. 1985

(b) 08126380

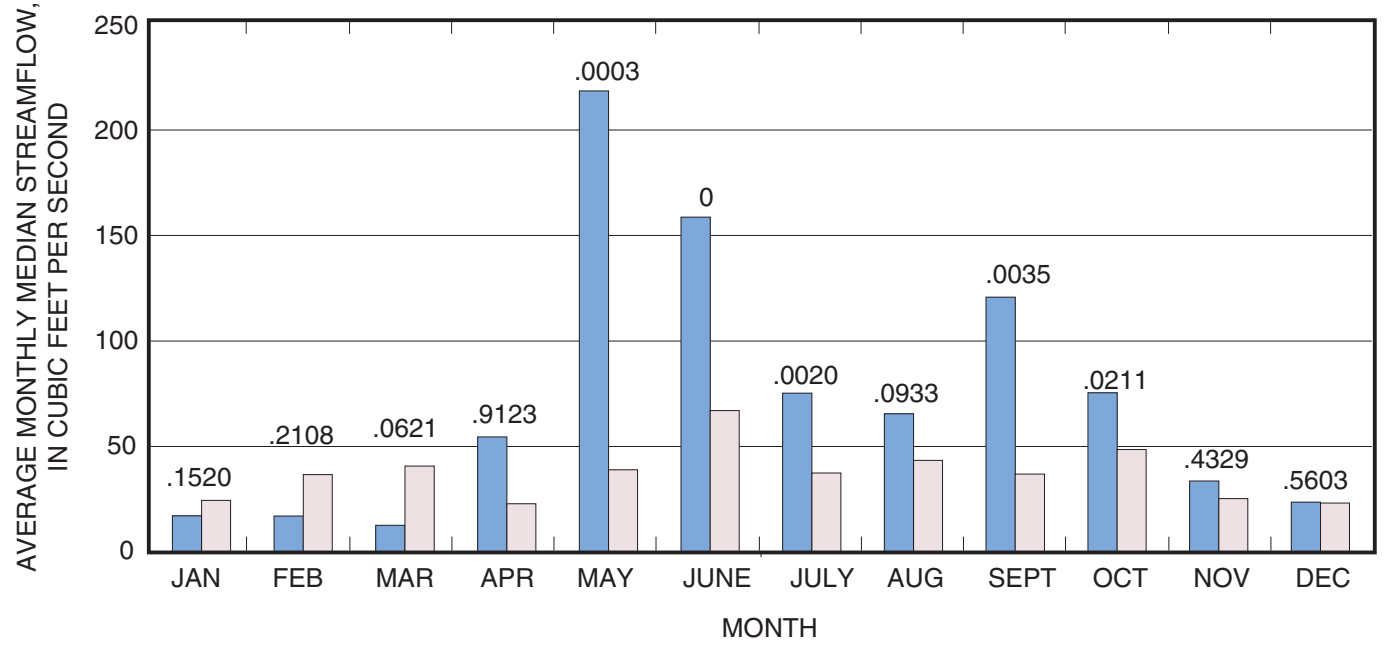

EXPLANATION

.0933 - p-value, Kruskal-Wallis test for significant difference between pre- and post-impoundment flow

Post-impoundment period

E.V. Spence Reservoir-June 1907-Dec. 1967

Pre-impoundment period

E.V. Spence Reservoir-Jan. 1969-Sept. 2000

Figure 4. Average monthly median streamflow for (a) Mountain Creek at Grand Prairie, Texas (08050100), during pre- and post-impoundment of Joe Pool Lake, and (b) for comparison, Colorado River near Ballinger, Texas (08126380), during pre- and post-impoundment of E.V. Spence Reservoir.

\section{Potential for Application of Indicators of Hydrologic Alteration Statewide}

The 1997 Texas Water Plan (Texas Water Development Board, 1997) acknowledges that past water development has modified aquatic communities, which in turn has affected the physical, chemical, and biological integrity of streams in Texas. Declines in the number of observed vulnerable fish species at a regional (river basin) level, and the fish community changes associated with these declines, appear to be attributable primarily to habitat modification associated with water development projects like reservoirs (Anderson and others, 1995). IHA analysis can provide a first approximation of the relative ecological risk to aquatic 


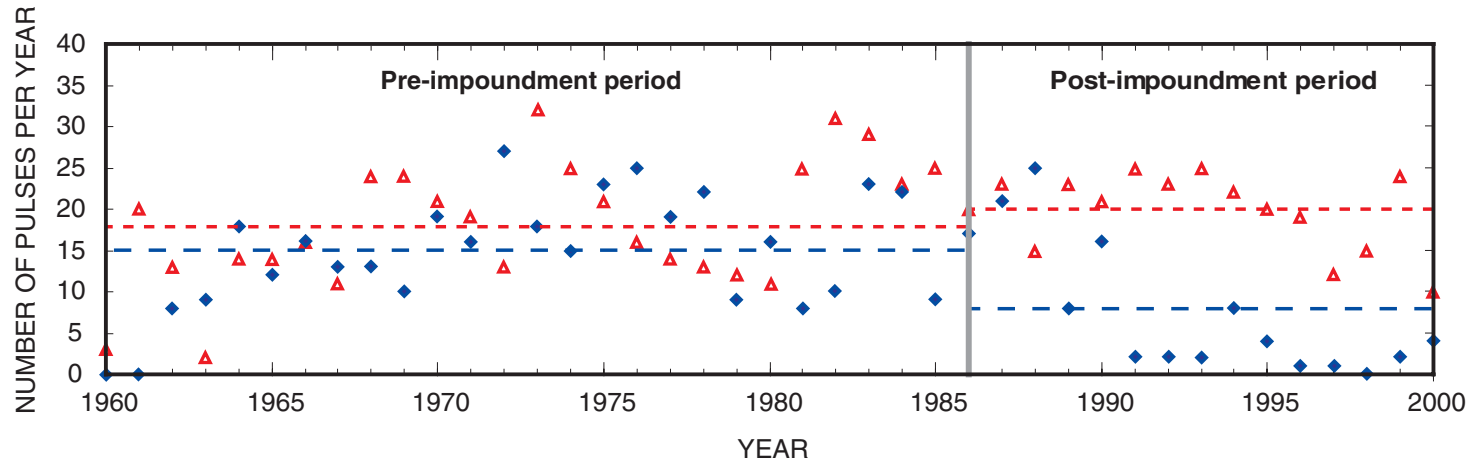

EXPLANATION

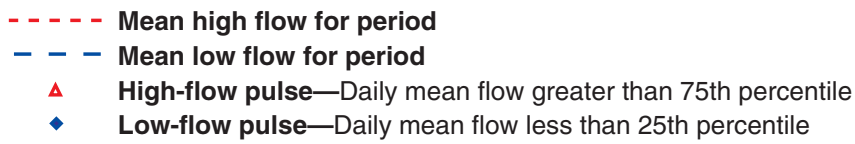

Figure 5. Annual frequency of high- and low-flow pulses for Mountain Creek at Grand Prairie, Texas (08050100), during pre- and post-impoundment of Joe Pool Lake.

ecosystems from altered natural flow regimes. The systematic assessment of existing streamflow data using IHA methods could document the extent of biologically relevant hydrologic alteration in Texas streams.

—Richard L. Kiesling

\section{References}

Anderson, A.A., Hubbs, C., Winemiller, K.O., and Edwards, R.J., 1995, Texas freshwater fish assemblages following three decades of environmental change: Southwest Naturalist, v. 40, no. 3, p. 314-321.

Bain, M.B., Finn, J.T., and Brooke, H.E., 1988, Streamflow regulation and fish community structure: Ecology, v. 69, p. 382-392.

Helsel, D.R., and Hirsch, R.M., 1992, Studies in environmental science 49-Statistical methods in water resources: Amsterdam, Elsevier, 522 p.

Leopold, L.B., Wolman, M.G., and Miller, J.P., 1992, Fluvial processes in geomorphology: New York, Dover Publications, Inc., $522 \mathrm{p}$.

Poff, N.L., and Ward, J.V., 1989, Implications of streamflow variability and predictability for lotic community structure-A regional analysis of streamflow patterns: Canadian Journal of Fisheries and Aquatic Sciences, v. 46, p. 1,805-1,818.

1990, Physical habitat template of lotic systems-Recovery in the context of historical pattern of spatio-temporal heterogeneity: Environmental Management, v. 14, p. 629645.

Richter, B.D., Baumgartner, J.V., Powell, Jennifer, and Braun, D.P., 1996, A method for assessing hydrologic alteration within ecosystems: Conservation Biology, v. 10, p. 1,1631,174 .
Richter, B.D., Baumgartner, J.V., Wigington, R., and Braun, D.P., 1997, How much water does a river need?: Freshwater Biology, v. 37, p. 231-249.

Sparks, R.E., 1992, Risks of altering the hydrologic regime of large rivers, in Cairns, J.B., and others, eds., Predicting ecosystem risk-Volume XX. Advances in modern environmental toxicology: Princeton, N.J., Princeton Scientific Publishing, p. 119-152.

Texas Water Development Board, 1997, Water for Texas-A consensus-based update to the State Water Plan-Volume 2. Technical planning appendix: Texas Water Development Board Document No. GP-6-2 [variously paged].

Any use of trade, product, or firm names is for descriptive purposes only and does not imply endorsement by the U.S. Government.

\section{Information on hydrologic data related to this study can be obtained from:}

District Chief

U.S. Geological Survey Phone: (512) 927-3500

8027 Exchange Dr.

Austin, TX 78754-4733

FAX: (512) 927-3590

E-mail: dc_tx@usgs.gov

http://tx.usgs.gov/ 